\title{
Profil uretritis gonokokus dan non-gonokokus di Poliklinik Kulit dan Kelamin RSUP Prof. Dr. R. D. Kandou Manado periode Januari - Desember 2012
}

\author{
${ }^{1}$ Alson Sambonu \\ ${ }^{2}$ Nurdjannah J. Niode \\ ${ }^{2}$ Herry E. J. Pandeleke
}

\author{
${ }^{1}$ Kandidat Skripsi Fakultas Kedokteran Universitas Sam Ratulangi Manado \\ ${ }^{2}$ Bagian Kulit dan Kelamin Fakultas Kedokteran Universitas Sam Ratulangi Manado \\ Email: sambonu41@yahoo.com
}

\begin{abstract}
Gonococcal urethritis (GU) is a sexually transmitted infection (STI) which is caused by Neisseria Gonorrhoeae bacteria. In GU, there is an urethral inflammation caused by negative Gram diplococcus ( its natural reservoir is human) and the symptoms are purulent discharge from external urethral orificium, burning sensation during urination, distal urethra itching, dysuria, vaginal or penile discharge, and erection pain. Non-Gonococcal Urethritis (NGU) is an urethral inflammation that is not caused by Gonococcal infection, but due to Chlamydia trachomatis and Ureaplasma urealyticum. The symptoms are penile discharge, burning sensation and pain during urination, and itching. This study aimed to obtain the profiles of gonococcal and non-gonococcal urethritis in Dermatovenereology Clinic of Prof. Dr. R. D. Kandou General Hospital Manado from January to December 2012. This was a retrospective descriptive study based on GU and NGU types, symptoms, sexual partner, occupation, and farmacological therapy. The results showed that of 74 STI cases there were $11 \mathrm{GU}$ cases (14.9\%) and 4 UNG cases (5.4\%). Most of GU and NGU patients were $25-44$ years $(n=10,66.7 \%)$, with dysuria $(n=11,73.3 \%)$, prostitute as sexual partner $(n=10,66.7 \%)$, working as entrepreneur $(n=12,80 \%)$, and farmacological therapy for GU is cefixime ( $n=9,81.8 \%)$ and for NGU is doxycyclin $(n=3,75 \%)$.
\end{abstract}

Keywords: gonococcal urethritis, non-gonococcal urethritis

\begin{abstract}
Abstrak: Uretritis gonore (UG) merupakan suatu penyakit infeksi menular seksual (IMS) yang disebabkan oleh kuman Neisseria gonorrhoeae. Pada UG terjadi peradangan uretra oleh diplokokus Gram negatif yang reservoir alaminya ialah manusia dan ditandai adanya pus yang keluar dari orifisium uretra eksternum, rasa panas, gatal di bagian distal uretra, disuria, polakisuria, keluar duh tubuh dari ujung uretra yang kadang-kadang disertai darah dalam urin, dan disertai rasa nyeri saat ereksi. Uretritis non Gonore (UNG) adalah suatu peradangan pada uretra yang bukan disebabkan oleh infeksi gonokokus seperti Chlamydia trachomatis dan Ureaplasma urealyticum dengan gejala seperti discharge dari penis, rasa terbakar atau sakit saat buang air kecil dan gatal. Penelitian ini bertujuan untuk mengetahui profil uretritis gonokokus dan non gonokokus di Poliklinik Kulit dan Kelamin RSUP Prof. Dr. R. D. Kandou Manado periode Januari-Desember 2012. Jenis penelitian ini deskriptif retrospektif berdasarkan jenis penyakit UG dan UNG, umur, keluhan, pasangan seksual, pekerjaan, dan terapi farmakologis. Hasil penelitian menunjukkan dari 74 kasus IMS terdapat 11 kasus UG (14,9\%) dan 4 kasus UNG (5,4\%). Penderita UG dan UNG terbanyak pada kelompok umur 25-44 tahun $(n=10,66,7 \%)$, dengan keluhan disuria $(n=11$, $73,3 \%)$, pasangan seksual dengan WPS $(n=10,66,7 \%)$, pekerjaan wiraswata $(n=12,80 \%)$, serta terapi farmakalogis pada UG ialah cefixime $(n=9,81,8 \%)$ dan pada UNG ialah doxycyclin $(n=3$, $75 \%)$.
\end{abstract}

Kata kunci: uretritis gonokokus, uretritis non gonokokus 
Uretritis adalah peradangan pada uretra dan terbagi menjadi Uretritis Gonokokus (UG) dan Uretritis non Gonokokus (UNG). Gonore merupakan penyakit yang mempunyai insidens yang tinggi di antara IMS. UNG yaitu peradangan uretra yang disebabkan oleh kuman lain selain gonokok. Gonore dalam arti luas mencakup semua penyakit yang disebabkan oleh Neisseria gonorheae. Penyebab Gonore adalah gonokok yang ditemukan oleh Neisser pada tahun 1879 dan baru diumumkan pada tahun $1882{ }^{1}$

Gonore terdapat dimana-mana di seluruh dunia dan merupakan penyakit kelamin yang terbanyak dewasa ini. Tidak ada imunitas bawaan setelah menderita penyakit ini. Juga tidak ada perbedaan mengenai kekebalan antar berbagai suku bangsa atau jenis kelamin atau umur. Diperkirakan setiap tahun tidak kurang dari 25 juta kasus baru ditemukan di dunia. Beberapa strain kuman gonokok yang resisten terhadap penisilin, quinolone dan antibiotik lainnya telah ditemukan beberapa tahun yang lalu dan membawa masalah dalam pengobatan yang telah tersebar di beberapa negara. $^{2}$

Menurut WHO, UG dan UNG merupakan masalah kesehatan lingkungan yang sangat penting. Penyakit ini ditransmisikan terutama melalui hubungan seksual dengan partner yang terinfeksi. WHO memperkirakan bahwa tidak kurang dari 25 juta kasus baru ditemukan setiap tahun di seluruh dunia. ${ }^{2,3}$ Di dunia, Gonore merupakan IMS yang paling sering terjadi sepanjang abad ke 20, dengan perkiraan 200 juta kasus baru yang terjadi tiap tahunnya. $^{4}$

Data dari Kelompok Studi Infeksi Menular Seksual Indonesia (KSIMSI) tahun 2012 melaporkan insidens gonokokus di Manado tahun 2007-2011 sebesar 31\% menempati urutan ke-2 di Indonesia, Medan (26,3\%), Padang (33,3\%), Bandung (28,7\%), Semarang (23,8\%), Yogyakarta (27,3\%), dan Denpasar (16,3\%). Gonore di Manado menempati urutan pertama bersama dengan
Padang dan Surabaya. ${ }^{5}$

UG merupakan suatu penyakit menular seksual yang disebabkan oleh kuman $N$. gonorrhoeae sedangkan kuman penyebab UNG ialah Chlamydia trachomatis dan Ureaplasma urealyticum. UG adalah penyakit kelamin berupa peradangan pada uretra, suatu diplokokus Gram negatif yang reservoir alaminya ialah manusia dan ditandai dengan adanya pus yang keluar dari orifisium uretra eksternum, rasa panas, gatal dibagian distal uretra, disuria, polakisuria, keluar duh tubuh dari ujung uretra yang kadang-kadang disertai darah dalam urin dan disertai rasa nyeri saat ereksi. Infeksi ini menular melalui aktifitas seksual dan umumnya penularan gonokokus melalui hubungan kelamin yaitu secara genio-genital, oro genital, dan ano genital tetapi juga dapat menular melalui pakaian, handuk dan sebagainya. ${ }^{6-8}$

UNG adalah suatu peradangan pada uretra yang bukan disebabkan oleh infeksi gonokokus tetapi oleh Chlamydia trachomatis dan Ureaplasma urealyticum dengan gejala seperti discharge dari penis, rasa terbakar atau sakit saat buang air kecil dan gatal. ${ }^{6-8}$

Pada pengobatan UG dan UNG, semua pasangan seksual berisiko harus dinilai dan ditawarkan pengobatan serta menjaga kerahasiaan pasien. Cefixime dan ceftriaxone ialah sefalosporin generasi ketiga yang direkomendasikan sebagai terapi lini pertama untuk UG. Cefixime diberikan per oral dalam dosis tunggal sedangkan ceftriaxone diberikan per injeksi intramuskular. Pada pengobatan UNG, azitromisin dan doksisiklin merupakan terapi lini pertama yang diberikan per oral. ${ }^{1,9,10}$

Pemahaman mengenai UG dan UNG pada laki-laki serta penanganan awal sangat dibutuhkan untuk mencegah komplikasi penyakit dan penularan lebih lanjut.

\section{METODE PENELITIAN}

Penelitian ini bersifat deskriptif retrospektif. Data diambil dari buku register penyakit menular seksual pasien 
laki-laki dengan UG dan UNG di Poliklinik Kulit dan Kelamin RSUP Prof. Dr. R.D. Kandou Manado.

Populasi mencakup seluruh pasien yang datang berobat ke Poliklinik Kulit dan Kelamin pada tahun 2012 di Manado. Sampel yaitu semua pasien laki-laki yang menderita UG dan UNG yang berobat ke RSUP Prof. Dr. R. D. Kandou Manado selama periode 1 Januari 2012 - 30 Desember 2012. Variabel penelitian meliputi jenis penyakit, umur, pekerjaan, pasangan seksual, keluhan, dan jenis terapi farmakologis.

\section{HASIL PENELITIAN}

Tabel 1 memperlihatkan dari 74 kasus IMS di RSUP Prof. Dr. R. D. Kandou pada tahun 2012 terdapat 11 kasus baru UG (14,9\%), 4 kasus baru UNG (5,4\%) dan 59 kasus baru IMS lain (79,7\%).

Tabel 1. Distribusi Jenis Penyakit IMS di RSUP Prof. Dr. R. D. Kandou pada Tahun 2012

\begin{tabular}{lcc}
\hline Jenis Penyakit & $\begin{array}{c}\text { Jumlah } \\
\text { Penyakit }\end{array}$ & (\%) \\
\hline UG & 11 & 14,9 \\
UNG & 4 & 5,4 \\
IMS Lain & 59 & 79,7 \\
Total & 74 & 100 \\
\hline
\end{tabular}

Tabel 2 menunjukkan kelompok umur terbanyak untuk pasien UG dan UNG di RSUP Prof. Dr. R.D. Kandou pada tahun
2012 yaitu kelompok 25-44 tahun dengan jumlah 10 orang (66,7\%), diikuti kelompok umur 15-24 tahun yang berjumlah 3 orang (20\%) dan kelompok umur 45-64 tahun yang berjumlah 2 orang (13,3\%).

Tabel 3 menunjukkan keluhan paling banyak pada pasien UG dan UNG di RSUP Prof. Dr. R. D. Kandou pada tahun 2012 yaitu disuria sebanyak 11 orang $(73,3 \%)$, diikuti piuria sebanyak 3 orang (20\%) dan pruritus sebanyak 1 orang (6,7\%).

Tabel 4 menunjukkan pasangan seksual pasien UG dan UNG di RSUP Prof. Dr. R. D. Kandou pada tahun 2012 yang terbanyak yaitu WPS dengan jumlah 10 orang $(66,7 \%)$, diikuti istri sendiri yang berjumlah 3 pasien (20\%), dan pacar yang berjumlah 2 orang (13,3\%).

Tabel 5 menunjukkan pekerjaan paling banyak pada pasien UG dan UNG tahun 2012 yaitu wiraswasta dengan jumlah 12 orang (80\%), diikuti PNS, petani, dan mahasiswa yang masing-masing berjumlah 1 orang $(6,7 \%)$.

Tabel 6 menunjukkan terapi UG dan UNG paling banyak di RSUP Prof. Dr. R. D. Kandou pada tahun 2012 Yaitu pada pasien UG ialah cefixime dengan jumlah 9 orang $(81,8 \%)$, diikuti azithromycin dan kombinasi cefixime + doxycyclin yang masing-masing berjumlah 1 orang $(9,1 \%)$ serta pada pasien UNG ialah doxycyclin dengan jumlah 3 orang (75\%), diikuti levofloxacin yang berjumlah 1 orang (25\%).

Tabel 2. Distribusi pasien UG dan UNG di RSUP Prof. Dr. R. D. Kandou pada tahun 2012 berdasarkan kelompok umur

\begin{tabular}{ccccccc}
\hline \multirow{2}{*}{ Kelompok Umur } & \multicolumn{2}{c}{ UG } & \multicolumn{2}{c}{ UNG } & \multicolumn{2}{c}{ Total } \\
\cline { 2 - 7 } & $\begin{array}{c}\text { Jumlah } \\
\text { Pasien }\end{array}$ & \multirow{2}{*}{$\%$} & $\begin{array}{c}\text { Jumlah } \\
\text { Pasien }\end{array}$ & (\%) & $\begin{array}{c}\text { Jumlah } \\
\text { Pasien }\end{array}$ & \multirow{2}{*}{$\%)$} \\
\hline $5-14$ & 0 & 0 & 0 & 0 & 0 & 0 \\
$15-24$ & 2 & 18,2 & 1 & 25 & 3 & 20 \\
$25-44$ & 8 & 72,7 & 2 & 50 & 10 & 66,7 \\
$45-64$ & 1 & 9,1 & 1 & 25 & 2 & 13,3 \\
$\leq 65$ & 0 & 0 & 0 & 0 & 0 & 0 \\
Total & 11 & 100 & 4 & 100 & 15 & 100 \\
\hline
\end{tabular}


Sambonu, Niode, Pandeleke: Profil uretritis gonokokus dan non gonokokus ...

Tabel 3. Distribusi pasien UG dan UNG di RSUP Prof. Dr. R. D. Kandou pada tahun 2012 berdasarkan keluhan

\begin{tabular}{lcccccc}
\hline \multirow{2}{*}{ Keluhan } & \multicolumn{2}{c}{ UG } & \multicolumn{2}{c}{ UNG } & \multicolumn{2}{c}{ Total } \\
\cline { 2 - 7 } & Jumlah Pasien & $(\%)$ & Jumlah Pasien & $(\%)$ & Jumlah Pasien & $(\%)$ \\
\hline Disuria & 8 & 72,7 & 3 & 75 & 11 & 73,3 \\
Hematuria & 0 & 0 & 0 & 0 & 0 & 0 \\
Piuria & 2 & 18,2 & 1 & 25 & 3 & 20 \\
Pruritus & 1 & 9,1 & 0 & 0 & 1 & 6,7 \\
Total & 11 & 100 & 4 & 100 & 15 & 100 \\
\hline
\end{tabular}

Tabel 4. Distribusi pasien UG dan UNG di RSUP Prof. Dr. R. D. Kandou pada tahun 2012 berdasarkan pasangan seksual

\begin{tabular}{lcccccc}
\hline \multirow{2}{*}{ Pasangan } & \multicolumn{2}{c}{ UG } & \multicolumn{2}{c}{ UNG } & \multicolumn{2}{c}{ Total } \\
\cline { 2 - 7 } & Jumlah Pasien & $(\%)$ & Jumlah Pasien & $(\%)$ & Jumlah Pasien & $(\%)$ \\
\hline Istri & 3 & 27,3 & 0 & 0 & 3 & 20 \\
WPS & 6 & 54,5 & 4 & 100 & 10 & 66,7 \\
Pacar & 2 & 18,2 & 0 & 0 & 2 & 13,3 \\
Total & 11 & 100 & 4 & 100 & 15 & 100 \\
\hline
\end{tabular}

Tabel 5. Distribusi pasien UG dan UNG di RSUP Prof. Dr. R. D. Kandou pada tahun 2012 berdasarkan pekerjaan

\begin{tabular}{lcccccc}
\hline \multirow{2}{*}{ Pekerjaan } & \multicolumn{2}{c}{ UG } & \multicolumn{2}{c}{ UNG } & \multicolumn{2}{c}{ Total } \\
\cline { 2 - 7 } & Jumlah Pasien & $(\%)$ & Jumlah Pasien & $(\%)$ & Jumlah Pasien & $(\%)$ \\
\hline PNS & 0 & 0 & 1 & 25 & 1 & 6,7 \\
Petani & 1 & 9,1 & 0 & 0 & 1 & 6,7 \\
Buruh & 0 & 0 & 0 & 0 & 0 & 0 \\
Sopir & 0 & 0 & 0 & 0 & 0 & 0 \\
Tukang ojek & 0 & 0 & 0 & 0 & 0 & 0 \\
Mahasiswa & 1 & 9,1 & 0 & 0 & 1 & 6,7 \\
Pedagang & 0 & 0 & 0 & 0 & 0 & 0 \\
Atlet & 0 & 0 & 0 & 0 & 0 & 0 \\
TNI/POLRI & 0 & 0 & 0 & 0 & 0 & 0 \\
Wiraswasta & 9 & 81,8 & 3 & 75 & 12 & 80 \\
Pelayan & 0 & 0 & 0 & 0 & 0 & 0 \\
Pengangguran & 0 & 0 & 0 & 0 & 0 & 0 \\
Total & 11 & 100 & 4 & 100 & 15 & 100 \\
\hline
\end{tabular}

Tabel 6. Distribusi Pasien UG dan UNG di RSUP Prof. Dr. R.D. Kandou pada Tahun 2012 Berdasarkan Jenis Terapi Farmakologi

\begin{tabular}{lcccccc}
\hline Jenis Terapi & \multicolumn{2}{c}{ UG } & \multicolumn{2}{c}{ UNG } & \multicolumn{2}{c}{ Total } \\
\cline { 2 - 7 } Farmakologi & Jumlah Pasien & $\%$ & Jumlah Pasien & $\%$ & Jumlah Pasien & $\%$ \\
\hline Cefixime & 9 & 81,8 & 0 & 0 & 9 & 60 \\
Azitromycin & 1 & 9,1 & 0 & 0 & 1 & 6,7 \\
Doxycyclin & 0 & 0 & 3 & 75 & 3 & 20,0 \\
Levofloxacin & 0 & 0 & 1 & 25 & 1 & 6,7 \\
Kombinasi Cefixime + & 1 & 9,1 & 0 & & 1 & 6,7 \\
Doxycyclin & 11 & 100 & 4 & 100 & 15 & 100 \\
Total & & & & & &
\end{tabular}




\section{BAHASAN}

Pada penelitian ini didapatkan pada tahun 2012 di Poliklinik Kulit dan Kelamin serta Rekam Medik RSUP Prof. Dr. R. D. Kandou Manado ditemukan 74 kasus baru IMS, diantaranya 11 kasus UG (14,9\%), dan 4 kasus UNG (5,4\%). Hasil ini sejalan dengan hasil penelitian yang dilakukan oleh Silalahi ${ }^{6}$ yang mengambil data dari tahun 2009-2011 di RSUP Prof. Dr. R. D. Kandou Manado dengan jumlah pasien UG sebanyak 56 orang $(68,5 \%)$ dan pasien UNG sebanyak 26 orang (31,5\%).

Pada distribusi pasien UG dan UNG berdasarkan kelompok umur pada tahun 2012 yang terbanyak yaitu kelompok 25-44 tahun sebanyak 10 orang (66,7\%). Hasil penelitian ini sejalan dengan penelitian yang dilakukan oleh Silalahi ${ }^{6}$ dari tahun 2009-2011 di RSUP Prof. Dr. R. D. Kandou Manado yang terbanyak yaitu 2544 sebanyak 51 orang (62\%). Hal ini disebabkan kelompok umur tersebut merupakan kelompok umur yang aktif secara seksual, sehingga lebih berisiko terinfeksi berbagai penyakit infeksi menular seksual.

Pada distribusi pasien UG dan UNG berdasarkan keluhan pada tahun 2012 yang terbanyak yaitu disuria atau nyeri kencing dengan jumlah pasien 11 orang (73,3\%). Hasil penelitian ini sejalan dengan yang dilakukan oleh Silalahi ${ }^{6}$ dari tahun 20092011 di RSUP Prof. Dr. R. D. Kandou Manado yaitu nyeri kencing dengan jumlah 35 orang (42,7\%). Pasien laki-laki lebih merasakan sakit saat buang air kecil. Nyeri kencing adalah gejala khas infeksi saluran kencing bawah seperti sistitis dan uretritis.

Pada distribusi pasien UG dan UNG berdasarkan pasangan seksual pada tahun 2012 yang terbanyak yaitu wanita pekerja seksual dengan jumlah 10 orang (66,7\%). Hasil penelitian ini sejalan dengan penelitian yang dilakukan oleh Silalahi ${ }^{6}$ dari tahun 2009-2011 di RSUP Prof. Dr. R. D. Kandou Manado yaitu 38 orang (46,3\%). Hal ini disebabkan WPS termasuk dalam kelompok risiko tinggi tertular dan menularkan infeksi menular seksual sehingga pria yang berhubungan seks dengan WPS lebih beresiko tertular IMS, terlebih bila berhubungan seks tanpa menggunakan kondom.

Pada distribusi pasien UG dan UNG berdasarkan pekerjaan pada tahun 2012 yang terbanyak yaitu wiraswasta dengan jumlah 12 orang (80\%). Hasil penelitian ini berbeda dengan penelitian yang dilakukan oleh Silalahi ${ }^{6}$ dari tahun 2009-2011 di RSUP Prof. Dr. R. D. Kandou Manado pekerjaan yang terbanyak yaitu pegawai dengan jumlah 38 orang (46,4\%).

Pada penelitian ini ditemukan terapi farmakologi terbanyak pada pasien UG tahun 2012 yaitu cefixime dengan jumlah 9 orang $(81,8 \%)$ dan pasien UNG yaitu doxycyclin dengan jumlah 3 orang (75\%). Penelitian ini berbeda dengan penelitian yang dilakukan oleh Heryani AD pada tahun 2008-2010 di rumah sakit Al-Islam Bandung dimana terapi paling banyak yaitu siprofloksasin dengan jumlah 28 orang $(33,74 \%){ }^{11}$ Hal ini disebabkan karena protokol rumah sakit yang berbeda dalam hal penanganan UG dan UNG.

\section{SIMPULAN}

Dari hasil penelitian di Poliklinik Penyakit Kulit dan Kelamin RSUP Prof. Dr. R. D. Kandou Manado menggunakan data tahun 2012 terhadap kasus uretritis dengan penyebab infeksi menular seksual didapatkan kasus UG lebih sering ditemukan daripada UNG. Untuk kedua jenis uretritis, terbanyak pada kelompok usia 25-44 tahun, pekerjaan wiraswasta, dengan pasangan seksual wanita pekerja seksual, keluhan tersering nyeri saat berkemih, dan diterapi dengan cefixime.

\section{UCAPAN TERIMA KASIH}

Ucapan terima kasih ditujukan kepada dr. Renate T. Kandou, SpKK serta semua pihak yang secara langsung dan tidak langsung telah memberikan gagasan pada penulisan artikel ini.

\section{DAFTAR PUSTAKA}

1. Djuanda A, Hamzah M, Aisah S. Ilmu Penyakit Kulit dan Kelamin (6th ed). Jakarta: Fakultas Kedokteran 
Universitas Indonesia, 2010; p. 369-75.

2. Silitonga JT. Uretritis. Medan: Fakultas Kedokteran Universitas Sumatra Utara, 2009. [cited 2014 Oct 5]. Available from: http://repository.usu.ac.id/ bitstream/123456789/26065/4/Chapter \%20II.pdf.

3. Ernawati. Uretritis Gonore. Fakultas Kedokteran Universitas Kusuma Jaya Surabaya. 2010. [cited 2014 Oct 5]. Available from: http://elib.fk.uwks.ac.id /asset/archieve/jurnal/Vol\%20Edisi\%20 Khusus\%20Desember\%2010/URETRI TIS\%20GONORE.pdf.

4. Jawas FA, Murtiastutik D. Penderita Gonore di Divisi Penyakit Menular Seksual Unit Rawat Jalan Ilmu Kesehatan Kulit dan Kelamin RSU Dr. Soetomo Surabaya Tahun 2002-2006. Surabaya: Departemen Kesehatan Kulit dan Kelamin Fakultas Kedokteran Universitas Airlangga, 2008. [cited 2014 Oct 5]. Available from: http://journal.unair.ac.id/ilerPDF/BIKK _vol\%2020\%20no\%203_des\%202008_ Acc_4.pdf, akses 5 Oktober 2014).

5. Malik SR, Amin S, Anwar A, Amiruddin MD. Penyakit Menular Seksual. Makassar: Bagian Ilmu Kesehatan Kulit dan Kelamin Fakultas Kedokteran Universitas Hasanuddin, 2004; p. 6585.

6. Silalahi YDP, Suling PL, Kapantouw MG. 2011. Profil urretritis gonokokus dan non gonokokus pada proa di RSUP Prof. Dr. R. D. Kandou Manado. [cited
2014 Oct 5]. Available from: http://ejournal.unsraty.ac.id/index.php/e clinic/article/view/1178.

7. Lorraine SAP. Patofisiologi Jilid I (6th ed). Jakarta: EGC, 2006.

8. Gillespie CW, Manhart LE, Lowens MS, Golden MR. 2013. Asymptomatic urethritis is common and is associated with characteristic that suggest sexually transmitted etiology. Children's National Medical Center, Washington DC, USA. [cited 2014 Oct 5]. Available from: http://www.ncbi.nlm.nih.gov/ pubmed/23407472.

9. Clifton RD. 2010. Sexually Transmitted Diseases (STDs) Treatment Guidelines, Center for Disease Control and Prevention. [cited 2014 DEc 10]. Available from: http://www.cdc.gov/std/treatment/2010/ gonococcal-infection.htm.

10. Miller KE. 2006. Diagnosis and Treatment of Neisseria Gonorrhoeae Infection. American Family Physician. University of Tennessee College of Medicine. Tennessee. [cited 2014 Dec 10]. Available from: http://www.aafp.org/ afp/2006/0515/p1779.pdf.

11. Heryani AD. Insidensi, Karakteristik, dan Penatalaksanaan Penderita Gonore di Bagian Ilmu Kesehatan Kulit dan Kelamin di Rumah Sakit Al-Islam Bandung Periode Tahun 2008-2010. Bandung: Fakultas Kedokteran Universitas Islam Bandung, 2010. 